
\title{
25 Research Sourere \\ Estimation of Yield Loss of Jatropha Curcas Due to Aphthona Whitfieldi in Burkina Faso
}

\author{
Alizèta Sawadogo \\ Institut de l'Environnement et de Recherches Agricoles \\ Issaka Zida \\ Institut de l'Environnement et de Recherches Agricoles \\ Marc Kenis \\ CABI Switzerland \\ Souleymane Nacro ( $\nabla$ snacro2006@yahoo.fr) \\ Institut de l'Environnement et de Recherches Agricoles https://orcid.org/0000-0001-5231-1634
}

\section{Research Article}

Keywords: Jatropha curcas, Aphthona whitfieldi, yield loss, Burkina Faso, biofuel

Posted Date: October 20th, 2021

DOl: https://doi.org/10.21203/rs.3.rs-932443/v1

License: (c) (i) This work is licensed under a Creative Commons Attribution 4.0 International License.

Read Full License

Version of Record: A version of this preprint was published at BioEnergy Research on March 8th, 2022. See the published version at https://doi.org/10.1007/s12155-022-10427-z. 


\section{Abstract}

In Burkina Faso, the leaf beetle Aphthona whitfieldi is the main insect pest of the biofuel plant Jatropha curcas. The beetle affects plant growth and seed yield, but the impact on yield has never been properly quantified. This study was conducted on-station and on-farm in the district of Léo, southern Burkina Faso, in 2015. It aimed at evaluating the yield losses that $A$. whitfieldi inflicts to $J$. curcas. The first experiment used 25 caged trees in their first year of fruit production, on which various amounts of beetles were released. When 200 beetles were released, the defoliation level reached $55 \%$ and caused $61 \%$ of yield loss. Releases of 400 or more beetles caused a defoliation level of at least $74 \%$ and seed losses of $98 \%$. On-farm observations were made on attack levels and seed yields in three different types of plantations, i.e. pure plantations, plantations intercropped with food crops and hedges. These observations showed that defoliation levels over $50 \%$ were common in the three types of plantations, resulting in very low yields. This study shows the importance of beetle damage in the cultivation of $J$. curcas. This is likely one of the reasons for the very low yields, which, among other causes, led to the abandonment of $J$. curcas plantations in the region.

\section{Introduction}

Jatropha curcas L. (Euphorbiaceae), is native to Mexico or neighboring regions of Central America ([1]). The species was spread by humans all over the world a long time ago and is now domesticated in many tropical and sub-tropical regions of the world. In Burkina Faso, as in many other African countries, the shrub was introduced since colonization and, in the last two decades, it has been cultivated in all regions of the country.

Jatropha curcas is well known throughout the world for its different uses ([1]; [2]; [3]). Various parts of the plants are used in cosmetics and herbal medicine, as well as fuel wood. The plant is also used to prevent erosion and as living fence to protect crops. Indeed, the curtine, a toxin contained in the leaves, keeps animals away because of its bad smell and taste. However, the main purpose of the worldwide adoption of $J$. curcas in recent decades was the production of biofuel, its seeds containing oil that is suitable for biodiesel production ([4]; [5]). Waste products can also be used as fertilizers and to produce biogas. It was also claimed that $J$. curcas cultivation enhanced socioeconomic development while reclaiming marginal and degraded lands in semi-arid regions ([1]; [6]). However, seed yields have been much lower than expected, which, together with other factors such as the low price for seeds and the limited valorization of by-products, resulted in a dramatic decline of J. curcas plantations worldwide ([7]; [8]; [9]; [10]; [11]). Low yields largely resulted from the fact that plantations of $\mathrm{J}$. curcas were implemented on a global scale without the necessary crop improvement, proper field validation and standardization of agronomic practices and high quality certified planting materials ([12]). The occurrence of serious damage caused by pests and diseases, often largely unknown to the farmers, was often cited among the factors affecting yields and hampering the adoption of J. curcas ([13]; [12]; [14]; [11]), but there are very few studies relating pests and diseases to yield loss ([15]). 
Many insects, fungi, bacteria and viruses attack roots, stems, leaves, flowers and fruits of $J$. curcas in sub-Saharan Africa ([16]; [17]; [18]; [14]; [19]; [20]). Among these, beetles of the genus Aphthona (Col.: Chrysomelidae) are among the most prevalent. These are small insect pests whose adults feed on the leaf surface, causing many small holes.

These insects are particularly damaging to young plants, which can die from continuous defoliation [21]. Even when the plant is not killed, its growth and fruiting are severely hampered ([16]; [22]; [19]; [23]). While several species occur on J. curcas in Africa ([24]), in Burkina Faso, the species Aphthona whitfieldi Bryant is the most widespread and causes important damage on plants ([23]; [21]). It is also suspected to cause significant yield losses ([22]). Aphthona whitfieldi Bryant is a beetle of the Chrysomelidae family. According to [24], the large family Chrysomelidae is divided into 19 subfamilies including that of the subfamily Alticinae and brings together around 37,000 herbivorous species distributed throughout the world. The subfamily Alticinae includes more than 90 genera including the genus Aphthona. Almost every species is oligophagous and therefore feeds exclusively on plants belonging to the same family or even the same genus. Elliptical or oval in shape, these small Coleoptera measuring less than $2.5 \mathrm{~mm}$ are rather difficult to observe. Indeed, when disturbed, they propel themselves using their powerful hind legs much like a flea, hence their English name of "Flea beetles" [25]. The adult has a white color immediately after emergence then turns to the red color a week later which will be its final coloration (Picture 1).

Generally, flea beetles are pests that can disrupt the development of young plants and cause economic damage through their activity of peripheral or internal gnawing of the leaf blades of different crops [26].

Mating takes place on the shoots of plants, and adult females subsequently lay their eggs on the soil surface or in the soil, on or near the base of the stem. Females of $A$. whitfielditypically lay a total of $100-$ 300 eggs in their lifetime, in a series of small groups of $20-30$, every $3-5$ days ([27]; [28]). Normally, the stage of embryonic development takes an average of 18 days at $22^{\circ} \mathrm{C}$ ([28]). Newly hatched larvae begin to feed on very small roots first before attacking larger roots as they develop ([29]). Aphthona whitfieldi overwinters as diapausing larvae for 3-4 months in soil and on or near roots when temperature drops below $3^{\circ} \mathrm{C}$. Larval development begins in spring when the temperature reaches $26^{\circ} \mathrm{C}$ and pupation occurs in early summer ([28]; [29]). The adults emerge from the ground throughout the summer and begin to feed on the leaves and flowers. Adults can survive for up to 4 months ([30]). Adult flea beetles damage plants by feeding on the surface of leaves and stems, resulting in numerous small holes in the surface of the leaf as if small balls [31] have hit it. With intense feeding, damage can kill the plant, especially young plants ([32]). Aphthona whitfieldi uses many sensory signals (smell, taste and vision) to locate its host plants ([33]). This insect was identified by ([34)]) as the main insect pest of J. curcas in Sub-Saharan Africa. It is widespread in Mali, Burkina Faso, Guinea, Ghana, Nigeria, Sudan and South Sudan. Aphthona whitfieldi is an oligophagous insect since in Burkina Faso, it is associated only with plant species of the genus Jatropha [(35)]). However, so far, there is no data in the scientific literature that can relate the damage caused by $A$. whitfieldi to yield losses. This study was conducted in Southern Burkina Faso with the aim of assessing the real impact of $A$. whitfieldi on yield and to relate visual damage levels to yield loss, to contribute to a more effective control of this insect pest in the region. 


\section{Materials And Methods}

The study was conducted both under semi-controlled conditions on-station and in farmers' fields.

\section{On-station experiment}

This experiment was implemented in the Fasobiocarburant SARL site (N11.15398 W002.07701) in Léo, Sissili province in southern Burkina Faso, from September 22 to November 13, 2015.

The experimental design included five replicates and five treatments. Each replicate consisted of a line of $J$. curcas trees randomly chosen. The five treatments represented the various numbers of beetles released in field cages. The treatments included:

- Control (T0): 0 adult of $A$. whitfieldi;

- T1: 200 adults of $A$. whitfieldi,

- T2: 400 adults of $A$. whitfieldi,

- T3: 800 adults of $A$. whitfieldi,

- T4: 1,000 adults of $A$. whitfieldi.

The experiment was implemented in a pure plantation of J. curcas and shrubs were planted in 2012 and were entering their first year of production. The plants of $\mathrm{J}$. curcas used in the current study did not come from a breeding program but from ordinary Jatropha curcas' plantation. This plantation was very well cared for and had few insect pests at the beginning of the experiment. In fact, this plantation was ploughed and well weeded, unlike to the other $J$. curcas'plantations of the study area. Twenty-five shrubs (five lines each consisting of five shrubs) of this plantation with no fruits or flowers and no symptoms of attack were chosen randomly. Selected shrubs were covered by a gauze cage $(1.5 \mathrm{~m}$ high and $1 \times 1 \mathrm{~m}$ wide). An opening with a zipper was made on all four sides of the cages to facilitate fruit picking.

We used a total of 12,000 adults of $A$. whitfieldi to infest the caged shrubs. These adults of $A$. whitfieldi were captured alive in 30 plantations in a radius of $15 \mathrm{~km}$ around the city of Léo, by observing leaves of infested shrubs. The collected beetles were put together in a plastic container $(10 \mathrm{~cm}$ high and $15 \mathrm{~cm} \times$ $12 \mathrm{~cm}$ ) with the two lateral sides and the mesh cover before being released into the gauze cages for $J$. curcas'plant infestation.

The collected beetles were released randomly to the different treatments. All caged shrubs were infested the same day and the shrubs were followed until the end of the experiment. Each week until fruit harvesting, the level of defoliation of each infested shrub was assessed according to the method of Sawadogo et al. [23]. Damage was assessed on ten leaves by considering the average percentage of surface area of the leaf damaged by $A$. whitfieldi (i.e. the surface where photosynthesis cannot take place due to direct feeding or drying caused by the insect pest). The evaluation of the damaged leaf area was done visually by two assessors. These assessors evaluated the leaf damage together, plant by plant, each time referring to the predefined scale.

The average attack was scored as follows: $<1 \%$ (average $0.5 \%$ ) of leaf surface damaged; 
1-5\% (average 3\%); $5-20 \%$ (average $12.5 \%$ ); $20-50 \%$ (average $35 \%$ ); $50-90 \%$ (average $70 \%$ ); and $>90 \%$ (average 95\%). The average percentages of infestation of each of the five trees were then averaged to assess the score per treatment at the end of the experiment.

Ripe fruits were collected weekly. The ripe fruits of a shrub were put together in a labelled plastic bag. Once in the laboratory, the harvested fruits were first weighed with a precision balance and then peeled. The seeds were dried in the shade for a week and then weighed.

\section{On-farm observations}

The on-farm observations were carried out in six farmers' fields infested by $A$. whitfieldi in a radius of 20 $\mathrm{km}$ from the Fasobiocarburant SARL site in Léo. The plantations were of three types: two pure plantations, two plantations intercropped with corn and soybean and two hedges (living fences). Fields were selected to include all types of Jatropha plantations in the sample but since there were few differences observed in defoliation level among these plantation types as observed in [23]) and since sample sizes per plantation type were low, all plantations were analyzed together without taking the type of plantation into account. All plantations were of the same age as the one of the on-station experiment. In each of these plantations we selected, on September 29, five trees with a high attack of $A$. whitfieldi and five trees with average attack (there was no tree with low or no attack in plantations that included heavily attacked trees). Attack levels were evaluated using the same method as on-station experiment. The heavily infested trees were defined as those with a minimum attack rate of $50-70 \%$ at the starting day and the moderately damaged trees as having a maximum of $20-50 \%$ attack rate at the starting date. Every two weeks, the selected plants were observed and the evolution of the attack levels was recorded. The observations on the attack levels by $A$. whitfieldi were performed four times until the end of the experiment, on 10 November 2015. The average damage levels were computed at the end of the experiment.

When mature, all fruits were harvested tree by tree, bagged and labeled. Once in the laboratory, the fruits and seeds were treated as in the on-station experiment.

\section{Statistical analysis}

Data collected on the effect of $A$. whitfieldiattacks on yield of J. curcas were entered with Excel 2013 software and subjected to statistical analysis using $\mathrm{R}$ software version 3.6.0. The parameters analyzed included the level of defoliation, the number of harvested fruits and, the number of seeds per tree. To do this, the data were first subjected to the Shapiro Wilk test to verify normality. Since the data did not follow a normal distribution, a nonparametric Kruskal Wallis analysis was performed.

Significantly different means were separated by the Smallest Significant Fischer's Difference (LSD) test at the $5 \%$ threshold.

Yield losses were calculated in the on-station experiment according to the formula [35]:

$\mathrm{P} \%=(\mathrm{rm}-\mathrm{yi}) / \mathrm{rm} \times 100$

$\mathrm{P} \%=$ percentage of seed yield loss 
$\mathrm{rm}=$ seed yield in the control plants

$\mathrm{yi}=$ seed yield in the treatment $\mathrm{i}$

\section{Results}

\section{On-station experiment Mean defoliation of J. curcas}

The mean defoliation of $J$. curcas by $A$. whitfieldi revealed a highly significant difference between treatments (Chi-squared $=79.4293 ; P=2.301 \mathrm{e}^{-16}$ ). The defoliation level increased with the number of beetles introduced in the cage, from $22.8 \%$ for the control to $81.3 \%$ for treatment 4 , but there was no significant difference between the treatments $2-4$, i.e. from 400 to 1,000 insects introduced. The minor defoliation level observed in the control could be explained by the fact that individuals of $A$. whitfieldi accidentally entered the cages through small holes in the tissue.

\section{Number of harvested fruits}

The average number of harvested fruits per tree during the experiment significantly varied with the number of beetles introduced in the cages (Chi-squared $=59.6635 ; P=3.414 \mathrm{e}^{-12}$ ).

From the control trees we obtained an average of six fruits per tree. Plants that were infested with 200 adult $A$. whitfieldi (T1) provided an average of two fruits per tree, and from cages with 400,800 and 1,000 beetles hardly any fruit was collected (Fig. 2).

\section{Estimated yield losses}

The average yield of $J$. curcas seeds ranged from $13.36 \mathrm{~g} /$ tree for the control to $0.15-0.29 \mathrm{~g}$ for the treatments T2-4 (Table 1). A yield loss of $98 \%$ was observed when the average defoliation level increased from $23 \%$ to $75 \%$. The loss was $61 \%$ when the defoliation level increased to $55 \%$. 
Table 1

Average grain yield loss of J. curcas due to A. whitfieldi

\begin{tabular}{|lllll|}
\hline Treatment & $\begin{array}{l}\text { Average defoliation } \\
\text { rate }(\%)\end{array}$ & $\begin{array}{l}\text { Total yield per } \\
\text { treatment } \mathbf{( g )}\end{array}$ & $\begin{array}{l}\text { Yield } \\
\text { (g/tree) }\end{array}$ & $\begin{array}{l}\text { Average yield loss per } \\
\text { treatment (\%) }\end{array}$ \\
\hline T0 & 22.8 & 401 & $\begin{array}{l}13.3 \pm \\
3.0\end{array}$ & - \\
\hline T1 & 55.0 & 155 & $\begin{array}{l}5.16 \pm \\
3.4\end{array}$ & 61.4 \\
\hline T2 & 74.1 & 8 & $0.26 \pm$ & 98.0 \\
& & & 0.2 & \\
\hline T3 & 75.1 & 5 & $0.15 \pm$ & 98.9 \\
& & & 0.1 & \\
\hline T4 & 81.3 & 8 & $0.29 \pm$ & 97.8 \\
\hline
\end{tabular}

\section{On-farm observations}

The results of the analyzes carried out on the number of fruits and the yield according to the level of attack showed that attacks by insect pests have a negative impact on the production of $\mathrm{J}$. curcas. The heavily attacked plants, which showed an average defoliation rate of $81.68 \%$, produced one fruit with a yield of $2.79 \mathrm{~g} /$ tree (Table 2). As for moderately attacked plants (average defoliation rate of $38.25 \%$ ), the production per tree was three fruits with a yield of $7.36 \mathrm{~g}$ per tree. The level of insect attacks had a significant effect on the number of fruits (Table 2).

Table 2

Average infestation level of $J$. curcas by $A$. whitfieldi and average associated yield in on-farm plantations

\begin{tabular}{|llll|}
\hline Level of infestation & Average & Average number & Average yield \\
\hline & infestation level & of fruits/tree & $(\mathrm{g} /$ tree $)$ \\
\hline Heavily infested plants & $81.7 \pm 11.7 \%$ & $1.5 \pm 0.6$ & $2.8 \pm 1.6$ \\
\hline Moderately infested plants & $38.2 \pm 21.4 \%$ & $3.7 \pm 0.6$ & $7.3 \pm 1.6$ \\
\hline $\mathrm{F}(1 ; 238)$ & 379.9 & 6.9 & 7.2 \\
\hline $\mathrm{P}$ & $<0.00001$ & 0.00931 & 0.00782 \\
\hline
\end{tabular}

\section{Discussion}

The study on the assessment of yield losses due to A. whitfieldi on J. curcas in field cages showed that the defoliation level of the plant strongly related to the number of individual adults feeding on the plant. 
Introducing 400 adults or more in the cages induced a sufficient level of defoliation to cause a yield loss of $98 \%$. Surveys and observations on-farm showed that such high levels of defoliation are commonly observed in the field, causing substantial yield losses. This proportionality between defoliation rate and yield was also evidenced by other authors on other plants. For example, on sunflower, a defoliation of 46 to $66 \%$ resulted in a loss in yield of 15 to $70 \%$ ([36].

The leaf loss due to the attacks of $A$. whitfieldi blocks the process of photosynthesis in J. curcas and thereby influences the production of fruits. Fruit production depends on the number of flowers produced, the pollination of these flowers and of course the damage caused by pests depending on the phenological stage of the plant. The experimentation in a semi-controlled environment and on-farm environment was set up before the flowering phase; therefore the high rates of defoliation must have caused a low production of flowers explaining the low yields observed. Studies on other plants such as sunflowers have shown that strong defoliation occurring during the pre-flowering phase causes yield losses of around $92 \%$ ([37].

Other studies in Africa showed that beetles of the Aphthona genus are very damaging on J. curcas and can cause complete defoliation of plants resulting in the death of young plants, growth reduction and poor fruit production $[16,19,22,23,21,38,39]$. For example, in the Democratic Republic of Congo, unidentified species of the genus Aphthona were found to be responsible for serious damage to $J$. curcas. The adults attacked the foliage and fruits of the developing shrub and, in the absence of insecticide applications, the level of yield loss due to the insect pest could reach $90 \%[23,40]$. In the lower valley of the Senegal River, insects such as Stomphastis thraustica, Pempelia morosalis and Calidea panaethiopica caused abortion of flowers and fruits of J. curcas, resulting in yield losses ([40].

However, this study is the first one to quantify the important loss of fruits and seeds due to defoliation by the beetles. Other insects and diseases can seriously affect $J$. curcas cultivation in Africa and elsewhere $[14,22,38,41,42]$. This contradicts the early belief that $J$. curcas was resistant to pests because of its toxicity. It also highlights the fact that $J$. curcas adoption programmes were implemented without the necessary knowledge of its cultivation. For example, in India, one million hectares of land were planted with $J$. curcas but the results were anything but satisfactory because of the economic losses caused by the low seed production ([7]). Our study clearly illustrates that it is necessary to develop integrated pest management against Aphthona spp. and other pests. However, J. curcas also needs a fertile soil, a good maintenance and water, contradicting the early statements that it is resistant to drought and can produce a good yield in very poor soils. In our experiment, in addition to the impact of the insect pest, the general growing conditions of the shrub have affected the productivity of J. curcas. In our experiments, seeds yields were extremely low, even in the control plots with low insect damage. The plantations were young (at most 3 years old) but were not fertilized nor were they irrigated. It was not uncommon to see that most or all of the branches of a J. curcas tree did not bear any fruit. Such very low yields are common in Africa, even in older plantations [43], which largely contributed to the disinterest for the crop in recent years on the continent. 


\section{Declarations}

\section{Acknowledgments}

This project was funded by the Agence Française de Développement (AFD) through a grant made available by the Fonds Français pour l'Environnement (FFEM). The project was co-funded by the Fondation Fasobiocarburant. The implementation of the project was coordinated by l'Agence de Développement de la Coopération Internationale dans les domaines de l'Agriculture, de l'alimentation et des espaces ruraux (ADECIA), France. MK's contribution

was supported by CABI with core financial support from its member countries (see https://www.cabi.org/what-we-do/how-we-work/cabi-donors-and-partners/ for details). Authors thank Mr Yacouba Nignan for his assistance in the field.The fellowship granted by IFS to the first author is also acknowledged.

\section{Funding}

This project was funded by the Agence Française de Développement (AFD) through a grant made available by the Fonds Français pour l'Environnement (FFEM). The project was co-funded by the Fondation Fasobiocarburant. The implementation of the project was coordinated by l'Agence de Développement de la Coopération Internationale dans les domaines de l'Agriculture, de l'alimentation et des espaces ruraux (ADECIA), France. MK's contribution

was supported by $\mathrm{CABI}$ with core financial support from its member countries (see https://www.cabi.org/what-we-do/how-we-work/cabi-donors-and-partners/ for details).

\section{Conflict of interest}

Authors declare that there is no conflict of interest.

\section{Availability of data and material}

Data of this manuscript are available.

\section{Code availability}

Not applicable here.

\section{Ethics approval}

All authors approved the ethics of the journal

\section{Consent to participate}

All authors consented to participate in the preparation of this manuscript. 


\section{Consent for publication}

All authors consented to the publication of this manuscript.

\section{Authors' contributions}

Souleymane Nacro and Alizèta Sawadogo designed the experiment. Alizèta Sawadogo implemented the experiment and coordinated the collection of the data. Data were analyzed by Alizèta Sawadogo with the assistance of Souleymane Nacro, Marc Kenis and Issaka Zida. All authors participated in the preparation of the manuscript. They reviewed it carefully before approving it.

\section{References}

1. Heller J (1996) Physic nut, Jatropha curcas L (Vol. 1) Biodiversity international

2. Gübitz GM, Mittelbach M, Trabi M (1999) Exploitation of the tropical oil seed plant Jatropha curcas L. Bioresource technology, 67(1): 73-82

3. Openshaw K (2000) A review of Jatropha curcas: an oil plant of unfulfilled promise. Biomass and bioenergy 19(1): 1-15

4. Achten WL, Verchot Y, Franken E, Mathijs V, Singh R, Muys AB (2008) Jatropha bio-diesel production and use. Biomass Bioenergy (32): 1063-1084

5. Kumar A, Sharma S (2008) An evaluation of multipurpose oil seed crop for industrial uses (Jatropha curcas L.): a review. Industrial crops and products 28(1):1-10.

6. Francis G, Edinger R, Becker K (2005) A concept for simultaneous wasteland reclamation, fuel production, and socio-economic development in degraded areas in India: need, potential and perspectives of Jatropha plantations. Natural Resources Forum (29): 12-24

7. Kant P, Wu S (2011) The extraordinary collapse of Jatropha as a global biofuel. Environmental Science and Technology, Volume 45, 7114-7115

8. Van Eijck J, Romijn H, Balkema A, Faaij A (2014a) Global experience with Jatropha cultivation for bioenergy: an assessment of socio-economic and environmental aspects. Renewable and Sustainable Energy Reviews (32): 869-889

9. Van Eijck J, Romijn H, Smeets E, Bailis R, Rooijakkers M, Hooijkaas N, Faaij A (2014b) Comparative analysis of key socio-economic and environmental impacts of smallholder and plantation based jatropha biofuel production systems in Tanzania. Biomass and Bioenergy (61): 25-45

10. Castro-Gonzales N F (2016) International experiences with the cultivation of Jatropha curcas for biodiesel production. Energy (112): 1245-1258

11. Soto-Landeros F, Alcaraz-Meléndez L, Angulo-Escalante MA, Reynoso-Granados T, Cruz-Hernández P, Herrera-Cedano F (2017) Pollen morphology of four species of Jatropha (Euphorbiaceae), including toxic varieties, in Northwestern Mexico. Rev Biol Trop 65 (2): 799-806 
12. Edrisi S A, Rama K D, Vishal T, Mansi B, Pankaj S, Sarah J, Singh H B,-Nandita S, Abhilash P C (2015) Jatropha curcas L. : A crucified plant waiting for resurgence, Science Direct, Volume 41, p.855-862

13. Muys BL, Norgrove T, Alamirew R, Birech E, Chirinian Y, Delelegn A, Ehrensperger CA, Ellison A, Feto B, Freyer (2014) Integrating mitigation and adaptation into development: the case of Jatropha curcas in Sub-Saharan Africa. GCB Bioenergy (6): 169-171

14. Ellison CA, Sawadogo A, Braman S, Nacro S (2015) First Report of Colletotrichum truncatum causing Stem Cankers on Jatropha curcas in Burkina Faso. Plant Disease, 99 : 14-20

15. Djimmy YW, Nacro S (2015) Estimation of Yield Loss of Jatropha curcas due to Calidea spp. (Heteroptera: Scutelleridae), in the Sub-Sudanian Zone of Burkina Faso. Intern Journ of Agric Inn and Res 3(5):1623-1627

16. Gagnaux $P$ (2009) Entomofauna associada à cultura da Jatrofa (Jatropha curcas L.) em Moçambique. Projecto final. Universidade Eduardo Mondlane, Faculdade de Agronomia Engenharia Florestal. Maputo, Mozambique, $79 \mathrm{p}$

17. Amsallem I (2014) Ravageurs et maladies du Jatropha. Jatroref, IRAM, ANADEB, Direction Générale de l'Environnement (DGE)-Bénin et Centre régional de promotion agricole (CERPA) du Zou-Collines (Bénin) 23p

18. Habou ZA, Adam T, Haubruge E, Mergeai G, Verheggen FJ (2014) Insects associated with Jatropha curcas Linn. (Euphorbiaceae) in West Niger. Journal of Insect Science 14, 255

19. Minengu JDD, Verheggen F, Mergeai G (2015) Dynamique et impact des principaux insectes ravageurs de Jatropha curcas $L$. dans deux systèmes de culture aux caractéristiques contrastées de la province de Kinshasa (République Démocratique du Congo). Tropicultura, Volume 33.3; p.163-175

20. Djimmy YW, Nacro S (2016) Study on the biology of Calidea spp. (Heteroptera: Scutelleridae), an insect pest of Jatropha curcas in South-Sudanian zone of Burkina Faso Annals of the Entomological Society of America 109(3): 335-342

21. Sawadogo A, Nacro S (2017) The Effect of Aphthona whitfieldi (Coleoptera: Chrysomelidae) on The Populations' Density and the Growth of Jatropha curcas in Burkina Faso. Advances in Entomology 5: 127-137.

22. Rouamba WM (2011) Inventaire des insectes ravageurs et des maladies fongiques du pourghère (Jatropha curcas L.) au Burkina Faso. Diplôme d'ingénieur du développement rural option: agronomie. Institut du Développement Rural, Université Polytechnique de Bobo-Dioulasso, Burkina Faso $68 \mathrm{p}$

23. Sawadogo A, Nagalo E, Nacro S, Rouamba M, Kenis M (2015) Population dynamics of Aphthona whitfieldi (Coleoptera : Chrysomelidae), pest of Jatropha curcas, and environmental factors favoring its abundance in Burkina Faso. Journal of Insect Science, Volume 15, 108

24. Wikipedia, 2014. Jatropha curcas. http://fr.wikipedia.org/wiki/Jatropha_curcas, page consulted on August 2016 
25. Knodel, J. J., and D. L. Olson. 2002. Biology and integrated pest management of the crucifer ßea beetle in canola. North Dakota State Univ. Coop. Ext. Serv. Publ. E1234. North Dakota State University, Fargo, ND.

26. Oelhafen A. et Vogler U., 2014. Altises (Phyllotreta spp. ; Coleoptera : Chrysomelidae) sur brassicacées, Agroscope, Fiche technique, №7.

27. Gassmann., 1990. Aphtona lacertosa (Rosh.) (Coleoptera: Chrysomelidae): A candidate for the biological control of leafy spurge and cypress spurge in North America. International Institute of Biological Control, Delémont, Switzerland. Final report. P. 30

28. Volkovitsh M G., Dolgovskaya M.Y., Reznik S. Y.et Cristofaro M., 2000. The life history and biology of Aphthona russica sp. nov. (Coleoptera: Chrysomelidae: Alticinae), a potential biological control agent of leafy Spurge. Proceedings of the X International Symposium on Biological Control of Weeds 113 4-14 July 1999, Montana State University, Bozeman, Montana USA. Neal R. Spencer [ed.]. pp. 113116.

29. Skinner L. C., Ragsdale D. W. R., Hansen W., Chandler M. A. et Moon R. D., 2004. TemperatureDependent Development of Overwintering Aphthona lacertosa and A. nigriscutis (Coleoptera: Chrysomelidae): Two Flea Beetles Introduced for the Biological Control of Leafy Spurge, Environmental Entomology 33(2): 147-154

30. Jan J.J., 1998. Biology of Aphthona nigriscutis (Coleoptera: Chrysomelidae) in the laboratory. Annals of the Entomological Society of America. 90(4):433-437.

31. Borror D. J, Triplehorn C. A. et Johnson N. F., 1992. An introduction to the study of insects. Sixth edition. Harcourt Brace and Company, Orlando, Florida. USA. 875p.

32. Orwa C, Mutua A, Kindt R, Jamnadass R et Simons A. 2009. Agroforestree Database: a tree reference and selection guide, version 4.0. : Jatropha curcas. World Agroforestry Centre, Kenya. http://apps.worldagroforestry.org/treedb2/AFTPDFS/Jatropha_curcas.PDF

33. Hazzard R., Andersen C. et Verson M. 2002. Managing flea beetles on Brassica Crops. http://www.umassvegetable.org/growers_services/pdf_files/flea_beetle_factsheet.pdf

34. Biondi M, Urbani F, D'Alessandro P (2013) Revision of the Aphthona cookei species group in SubSaharan Africa: pests of Jatropha curcas L. in biodiesel plantations (Coleoptera, Chrysomelidae, Galerucinae, Alticini). Entomologia. DOI: 10.4081/entomologia.2013.e7.

35. Walker PT (1987) Empirical models for predicting yield loss caused by stem borers. In Crop Loss Assessment in Rice IRRI, Los Banos, Philippines pp. 131-138.

36. Hailé FJ., Higley L.G., Specht J.E., 1998. Soybean Cultivars and Insect Defoliation: Yield Loss and Economic Injury Levels, Agronomy Journal, 90, 3, 344-352.

37. Muro J., Irigoyen I., Militino A.F. et Lamsfus C., 2001. Defoliation Effects on Sunflower Yield Reduction, Agronomy Journal, 93, 3,634-637.

38. Ranga Rao GV, Marimuttu S, Wani SP, Rameshwar RV (2010) Insect pests of Jatropha curcas L. and their management. Information Bulletin. Patancheru, International Crops Research Institute for the Semi-Arid Tropics India 
39. Minengu JDD, Mobambo P, Mergeai G (2014) Influence de l'environnement et des pratiques culturales sur la productivité de Jatropha curcas L. en Afrique subsaharienne. Biotechnology, Agronomy, Society Environment (18): 290-300

40. Terren M., Mignon J., De clerck C., Jijakli H., Savery S., Jacquet de Haveskercke P., Winandy S. et Mergeai G, 2012. Principal disease and Insect pests of Jatropha curcas $L$. in the lower valley of the Senegal river, Tropicultura, 30, 4,222-229

41. Anitha, K., and K. S. Varaprasad. 2012. Jatropha pests and diseases, an overview, pp. 175-218. In N. Carels, M. Sujatha, and B. Bahadur (eds.), Jatropha, challenges for a new energy crop, Springer, New York.

42. Lama, A. D., T. Vuorisalo, and P. Niemela“. 2015. Global patterns of arthropod herbivory on an invasive plant, the physic nut (Jatropha curcas L.). J. Appl. Entomol. 139: 1-10.

43. Negussie A, Nacro S, Achten W, Norgrove L, Kenis M, Hermy M, Muys B (2015) Insufficient evidence of Jatropha curcas L. invasiveness: experimental observations in Burkina Faso. BioEnergy Research 8, 570-580 W, Sawadogo A, Nacro S 2016. Alternative host plants of Calidea panaethiopica (Hemiptera, Scutelleridae) and Aphthona whithfieldi (Coleoptera, Chrysomelidae), insect pests of Jatropha curcas, South Burkina Faso. Advances in Entomology, 4, 225-230.

\section{Figures}

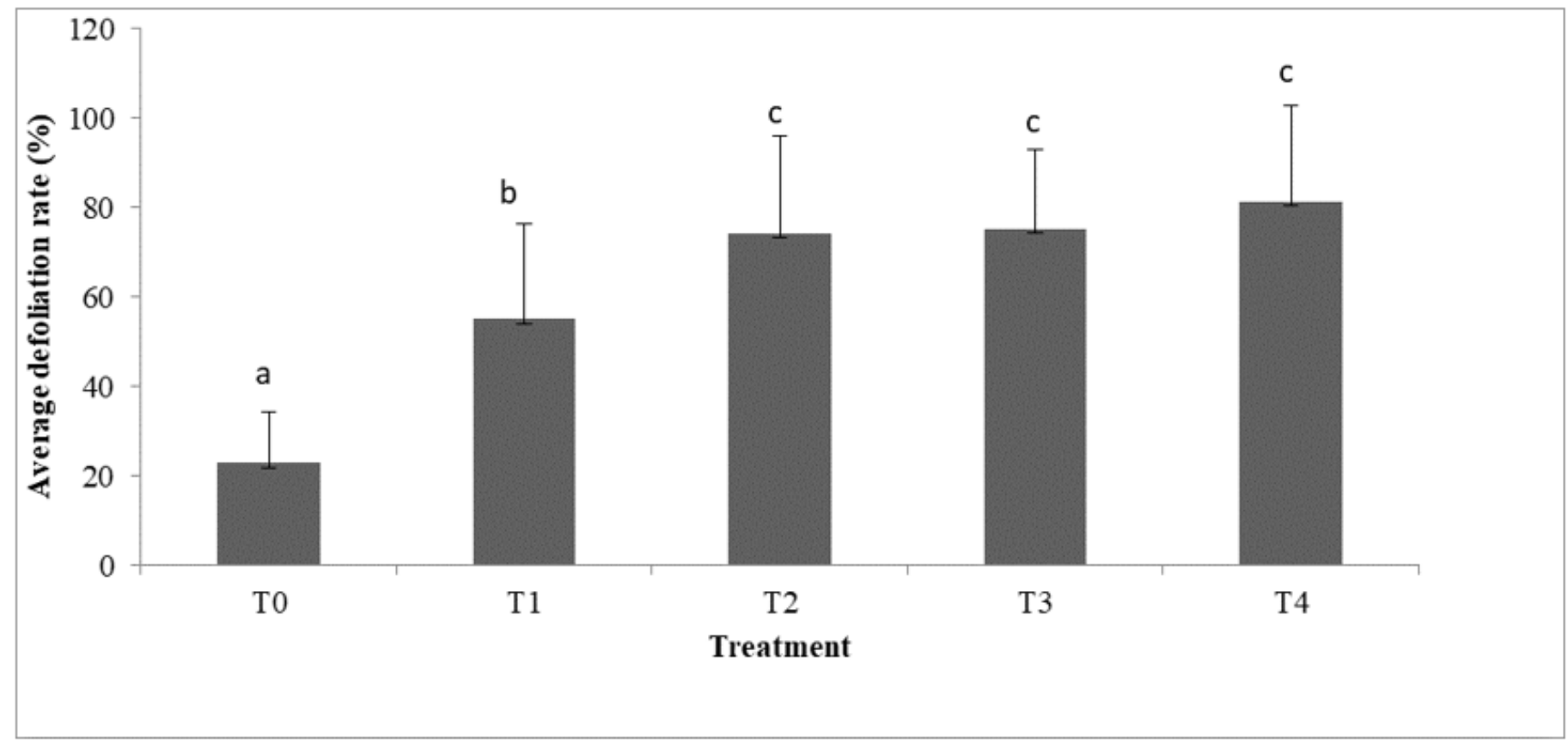

Figure 1

\section{Figure 1}


Mean defoliation level of Jatropha curcas The lines above the bars represent the standard deviation and the same letters above the vertical bars indicate homogeneous groups at the $5 \%$ threshold, Fischer LSD test.

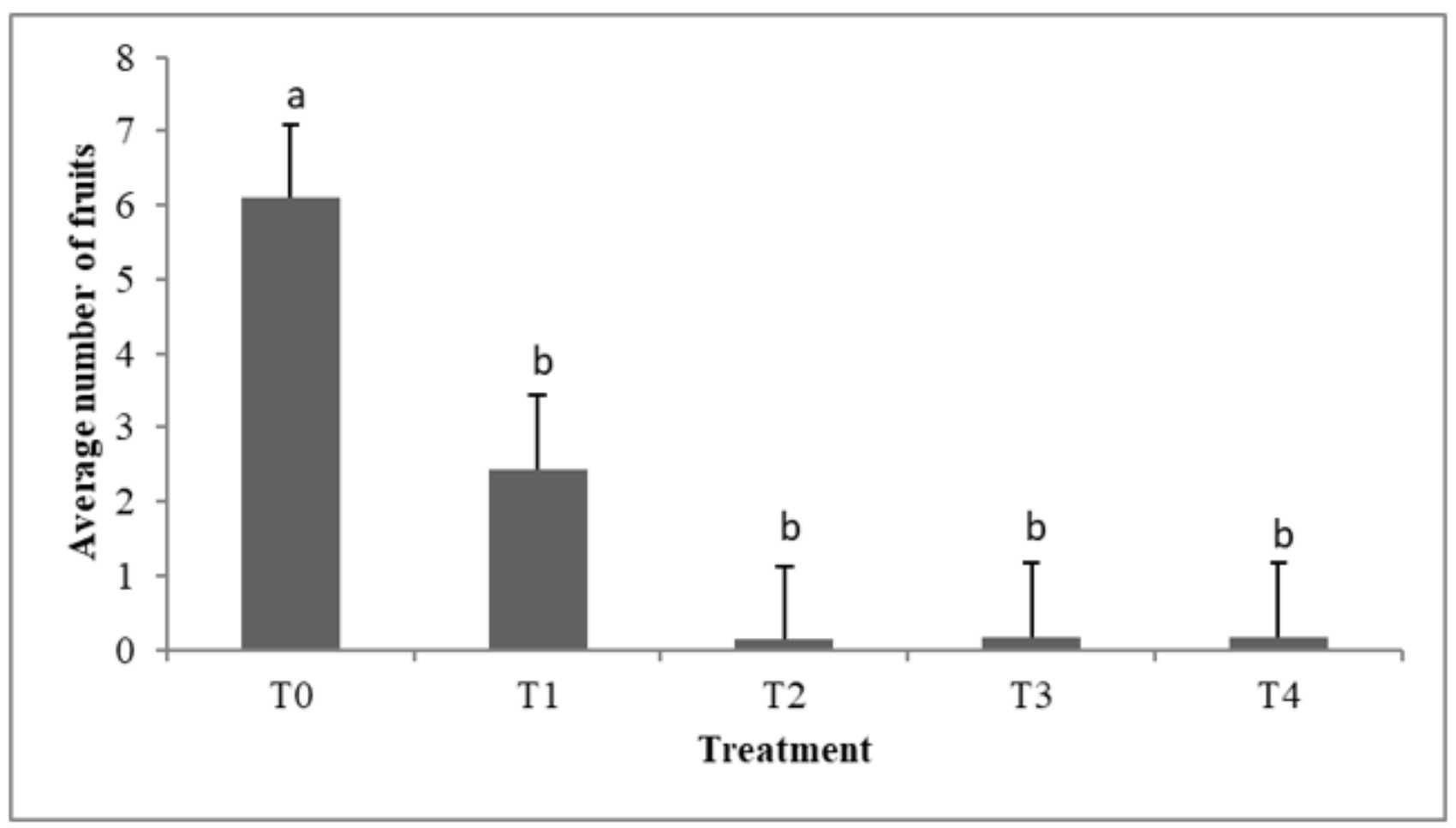

\section{Figure 2}

\section{Figure 2}

Average number of fruits harvested per tree according to the treatment The lines above the bars represent standard deviation and the same letters above the vertical bars indicate homogeneous groups at the $5 \%$ threshold, Fischer LSD test.

\section{Supplementary Files}

This is a list of supplementary files associated with this preprint. Click to download.

- Picture1.png 